\title{
CORRELATION BETWEEN IMMUNIZATION STATUS AND MOTHER'S HEIGHT, AND STUNTING IN CHILDREN 2-5 YEARS IN INDONESIA
}

\author{
Hubungan Kejadian Stunting dengan Status Imunisasi dan Tinggi Ibu pada Anak Usia 2-5 Tahun di \\ Indonesia
}

\begin{abstract}
Risna Nur Fajariyah ${ }^{1}$, Atik Choirul Hidajah ${ }^{2}$
${ }^{1}$ Faculty of Public Health, Universitas Airlangga, risna.nur.fajariyah-2015@fkm.unair.ac.id

${ }^{2}$ Department of Epidemiology, Faculty of Public Health, Universitas Airlangga, atik-c-h@ fkm.unair.ac.id

Corresponding Author: Atik Choirul Hidajah, atik-c-h@fkm.unair.ac.id, Department of Epidemiology, Faculty of Public Health, Universitas Airlangga, Ir. Dr. H. Soekarno Street, Mulyorejo, Surabaya, East Java, 60115, Indonesia
\end{abstract}

\section{ARTICLE INFO}

Article History:

Received July, $2^{\text {nd }}, 2019$

Revised form July, $23^{\text {rd }}, 2019$

Accepted January, $17^{\text {th }}, 2020$

Published online January, 28 ${ }^{\text {th }}, 2020$

\author{
Keywords: \\ Indonesia Family Live Survey wave \\ 5 ; \\ immunization status; \\ mother's height; \\ stunting
}

Kata Kunci:

Indonesia Family Live Survey wave 5 ;

tinggi ibu;

status imunisasi;

stunting

\begin{abstract}
Background: Stunting is a condition where the growth and development of a child fails during the first 1,000 days of life. The number of stunted children in Indonesia has increased from $35.60 \%$ in 2010 to $37.20 \%$ in 2013. Purpose: The aim of this study is to analyse the relationship between immunisation status and stunting in children 2-5 years. Methods: This is a secondary data analysis with cross-sectional study design. The data used for this study were obtained from Indonesia Family Live Survey wave 5 (IFLS-5). IFLS5 was conducted in 13 provinces from October 2014 until April 2015. The data were collected from 1,048 respondents aged 2-5 years in the IFLS-5 with completed age and height data. The observed variables were age, sex, immunisation status, history of infection, mother's height, mother's age during pregnancy, living area, and region. Results: This research shows that there is a relationship between immunisation status $(\mathrm{p}=0.01 ; \mathrm{OR}=1.78 ; 95 \% \mathrm{CI}=1.26<\mathrm{OR}<$ 2.52 ), mother's height ( $\mathrm{p}=0.00 ; \mathrm{OR}=1.41 ; 95 \% \mathrm{CI}=1.00<\mathrm{OR}<$ 1.98) and stunting in children aged $2-5$ years. Conclusion: Immunisation status and mother's height are associated with stunting in children aged $2-5$ years.
\end{abstract}

C2020 Jurnal Berkala Epidemiologi. Published by Universitas Airlangga. This is an open access article under CC-BY-SA license (https://creativecommons.org/licenses/by-sa/4.0/)

\section{ABSTRAK}

Latar Belakang: Stunting merupakan suatu kondisi pada anak dengan kegagalan pertumbuhan dan perkembangan dalam 1.000 hari pertama kehidupan. Persentase stunting di Indonesia terus mengalami peningkatan yaitu sebesar 35,60\% pada tahun 2010 naik menjadi 37,20\% pada tahun 2013. Tujuan: Penelitian ini bertujuan untuk mengalisis hubungan antara kejadian stunting dengan status imunisasi dan tinggi ibu pada anak usia 2-5 tahun. Metode: Penelitian ini merupakan penelitian yang menganalisis data sekunder dengan desain studi cross-sectional. Data yang digunakan adalah data Indonesia Family Live Survey (IFLS-5). Populasi penelitian adalah 1.048 responden yang berusia 2-5 tahun yang tercatat
How to Cite (APA): Fajariyah, R.N., \& Hidajah, A. C. (2020). Relationship between immunization status and mother's height with stunting in children 2-5 years in Indonesia. Jurnal Berkala Epidemiologi, 8(1), 89-96. https:/dx.doi.org/10.20473/ jbe.v8i12020.89-96 
sebagai responden pada IFLS-5 dengan tinggi dan usia yang tercatat secara lengkap. IFLS-5 menggunakan multistratified sampling sebagai teknik pengambilan sample. IFLS 5 dilaksanakan di 13 provinsi sejak Oktober 2014 hingga April 2015. Variabel yang diamati adalah usia anak, jenis kelamin anak, status imunisasi, riwayat penyakit infeksi, tinggi badan ibu, usia ibu saat hamil, daerah tempat tinggal dan wilayah provinsi (jawa dan non-jawa). Data dianalisis dengan analisis regresi logistik sederhana. Hasil: Penelitian ini menunjukkan bahwa terdapat hubungan antara status imunisasi ( $p=0,01 ; O R=1,78 ; 95 \% C I=1.26<O R<2.52)$, tinggi badan ibu ( $p=0,00 ; O R=1,41 ; 95 \% C I=1.00<O R<1.98)$ memiliki hubungan dengan kejadian stunting pada anak usia 2-5 tahun. Kesimpulan: Status imunisasi dan tinggi ibu memiliki hubungan dengan kejadian stunting pada anak usia 2-5 tahun.

(C2020 Jurnal Berkala Epidemiologi. Penerbit Universitas Airlangga. Jurnal ini dapat diakses secara terbuka dan memiliki lisensi CC-BY-SA (https://creativecommons.org/licenses/by-sa/4.0/)

\section{INTRODUCTION}

Stunting is growth and development failure in children caused by long-term insufficient energy intake and recurrent infection in the first 1,000 days of life. The World Health Organization (WHO) defines stunting as the height-age-z-score less than -2 SD from the WHO growth standard median. Malnutrition can cause delayed growth and development and increase the risk of infection and premature death in children. Short-term effects of stunting cause slowed growth and development, a higher chance to get infections, and early death in children. Stunted children will have a higher risk of suffering from chronic diseases and, in the long term, from poor cognitive development. Indonesia is now facing multiple malnutrition burdens, and stunting has caught government attention. Stunting can affect children's development not only in the short term but in the long term too. Indonesia is in fifth place worldwide for stunted children and second place in Southeast Asia after Laos (TNPK, 2017).

The stunting prevalence in Indonesia rose from $35.60 \%$ in 2010 to $37.20 \%$ in 2013 , based on Indonesia Basic Health Research (Riskesdas) 2013, East Nusa Tenggara province has the highest prevalence of stunting in Indonesia and is among 20 regions with prevalence higher than national prevalence (Ministry of Health RI, 2013). The 2017 Nutritional Status Observation results showed that the proportion of children aged 0-59 months who were stunted was $29.60 \%$. The prevalence was higher from 2016, at $27.50 \%$ (Ministry of Health RI, 2018). The WHO conceptual framework on child stunting classified the causes of stunting in terms of several factors. Household and family factors, inadequate complementary feeding, breastfeeding, and infection are all factors related to stunting in children (Beal, Tumilowicz, Sutrisna, Izwardy, \& Neufeld, 2018). These factors are followed by contextual factors: health factor, economic factor, sociocultural factor, and environmental factor. Those factors can be the potential causes of stunting in Indonesia. The WHO Conceptual Framework on Childhood Stunting describes the complex interactions between environment, household conditions, socioeconomic, and cultural influences as the cause of stunting (RAND, 2015; WHO, 2014).

Stunting has a direct and indirect relationship with death and disability. The occurrence of stunting at the beginning of life can disrupt development and growth, because the first two years constitute the best growth period for children. The growth failure is irreversible, so if a child experiences growth and development failure, they will not improve (TNPK, 2017). Short-term effects of stunting can cause growth retardation and obstruction of development, increase the risk of infection, and lead to early death in children. Low productivity and higher risk for choric disease is the long-term effect of stunting in children. Because stunting can interfere with economic growth, increase poverty, and widen inequality, it is not only a problem for children and families but also for the country, if it is not well handled (Hanandita \& Tampubolon, 2015). A recent study showed that stunting is associated with lower earnings in adulthood, chronic disease, and development retardation in children (Leroy \& 
Frongillo, 2019). Stunting must be prevented in the pre-conception period and the early 1,000 days of life. This study aims to determine the relationship between immunisation status and mother's height and stunting in children aged 2 to 5 years.

\section{METHODS}

This was a secondary data analysis on Indonesia Family Life Survey wave 5 (IFLS-5) with a cross-sectional study design. Indonesia Family Life Survey wave 5 was fielded in 2014 until 2015 in 13 provinces in Indonesia. It collects information on individual, household, and community-level data using multistage stratified sampling. It is a longitudinal, continued socioeconomic and health survey.

The observed variables for stunting were sex, age, mother's age, mother's height, immunisation status, having a history of infection, living area, and region area. Children aged 2-5 years that were recorded in the IFLS 5 database were included in this study. Stunting status was obtained from children's height per age less than -2SD from the WHO growth standard median. Respondent characteristic information was obtained from book $3 \mathrm{~A}$, book 4 , and book 5 questionnaire, which included questions on sex (male and female), age ( 2 to 5 years old), immunisation status (grouped to 'complete' and 'incomplete'), having history of infection (grouped to 'yes' and 'no'), living area (urban and rural), mother's height $(\leq 150 \mathrm{~cm}$ and $>150 \mathrm{~cm}$ ), and mother's age ( $\leq 20$ or $>35$ and $21-$ 35 years old). Data were cleaned and analysed using the computer program Stata. Descriptive statistics were used for all the variables studied. This study used simple logistic regression $(\alpha=0.05$ and $95 \%$ of confidence interval) for statistical analysis to test the association and risk in immunisation status, mother's height, and stunting. The IFLS survey was ethically approved by Institutional Review Boards in the USA and Ethics Committees of Universitas Gadjah Mada, Yogyakarta in Indonesia. This survey was also ethically approved by Ethics Committees of Faculty of Dental Medicine Universitas Airlangga, Surabaya.

\section{RESULTS}

The result of the descriptive analysis shows that among the total children, $171(16.32 \%)$ were stunted and $877(83.68 \%)$ were not. Table 1 shows that stunting mostly occurs in children aged 2
(17.65\%) and 3 years (17.48\%). The number of stunted children is less at age 4 and 5. Meanwhile, the number of non-stunted children is higher, along with older age. The proportion of male children who are stunted (18.30\%) is higher than female children (14.20\%) (Table 1). Most of the stunted children have a mother with a height of less than $150 \mathrm{~cm}(18.27 \%$ ) (Table 2). Table 1 shows that $15.90 \%$ of mothers of stunted children are aged less than 20 or more than 35 during pregnancy. Most of the non-stunted children have a mother aged 20-35. The proportion of stunted children is higher in urban (21.65\%) than in rural areas (Table 1). The proportion of children who live in the Java area and are stunted is greater (20.12\%) than children who live in a non-Java area. The proportion of stunted children with uncompleted immunisation status is higher (22.54\%) than stunted children with completed immunisation status (13.82\%). The statistics analysis shows that children with uncompleted immunisation are 1.78 more at risk of being stunted than children with completed immunisation status. The proportion of stunted children with mother's height $<150 \mathrm{~cm}(18.27 \%)$ is higher than stunted children with mother's height $>150 \mathrm{~cm}(13.68 \%)$. Children with a mother who has a height less than $150 \mathrm{~cm}$ are more likely to be stunted than children whose mother has a height of more than $150 \mathrm{~cm}$. The number of nonstunted children is also higher if they have completed immunisation status and mother's height is less than $150 \mathrm{~cm}$. According to the bivariate analysis, immunisation status $\mathrm{p}=0.01<(\alpha$ $=0.05)$ and mother's height $\mathrm{p}=0.00<(\alpha=0.05)$ are related to stunted children $2-5$ years old.

\section{DISCUSSION}

Stunting is a public health and nutrition problem that sometimes is late to be recognised (Dewana, Fikadu, Facha, \& Mekonnen, 2017). It has become a common problem in developing countries, as well as Indonesia. Stunting prevalence in Indonesia increased from $35.60 \%$ in 2010 to $37.20 \%$ in 2013 and keeps increasing (Ministry of Health RI, 2013).

\section{Child Age}

Stunting is a condition of growth retardation that happens in the first 1,000 day of life. The early life of children is critical for growth and development (de Onis \& Branca, 2016). According to a study from Rachmi, Agho, Li, \& Baur (2016) children have a higher risk of stunting at a young 
age (2-2.9 years). The research conducted by Hafid \& Nasrul (2017) showed that children aged 12-23 months are at higher risk than children aged 6-11 months. The number of older or younger children who are stunted is lower than children aged 3 and 4 years, according to the analysis. The number of stunted children decreases with age (Altare, Delbiso, Mutwiri, Kopplow, \& GuhaSapir, 2016). Children aged under 3 years are more at risk than children aged over 3 years. Prevention and early intervention are needed to ensure that mothers receive adequate energy intake during pregnancy, children receive adequate intake from breastfeeding in the first six months of life, and complementary feeding in the 7-23 month age group (de Onis \& Branca, 2016). According to Mazengia \& Biks (2018) a study in Ethiopia showed that illiterate mothers are a risk factor for stunting.

Table 1

Children Characteristic in Indonesia

\begin{tabular}{|c|c|c|c|c|c|c|}
\hline \multirow{3}{*}{ Characteristic } & \multicolumn{4}{|c|}{ Stunting } & \multirow{2}{*}{\multicolumn{2}{|c|}{ Total }} \\
\hline & \multicolumn{2}{|c|}{ Yes } & \multicolumn{2}{|c|}{ No } & & \\
\hline & $\mathrm{n}$ & $\%$ & $\mathrm{n}$ & $\%$ & $\mathrm{n}$ & $\%$ \\
\hline \multicolumn{7}{|l|}{ Child Age (years old) } \\
\hline 2 & 39 & 17.65 & 182 & 42.82 & 221 & 21.09 \\
\hline 3 & 43 & 17.48 & 203 & 32.58 & 246 & 23.47 \\
\hline 4 & 48 & 16.67 & 240 & 47.81 & 288 & 27.48 \\
\hline 5 & 41 & 13.99 & 252 & 46.15 & 293 & 27.96 \\
\hline \multicolumn{7}{|l|}{ Child Sex } \\
\hline Male & 99 & 18.30 & 442 & 81.70 & 541 & 51.62 \\
\hline Female & 72 & 14.20 & 435 & 85.80 & 507 & 48.38 \\
\hline \multicolumn{7}{|l|}{ History of Infection } \\
\hline Yes & 126 & 16.80 & 624 & 83.20 & 750 & 71.56 \\
\hline No & 45 & 14.56 & 264 & 85.44 & 309 & 29.48 \\
\hline \multicolumn{7}{|c|}{ Mother's Age during Pregnancy (years old) } \\
\hline$\leq 20$ or $>35$ & 46 & 16.85 & 227 & 83.15 & 273 & 26.05 \\
\hline $21-35$ & 125 & 15.90 & 661 & 84.10 & 786 & 75.00 \\
\hline \multicolumn{7}{|l|}{ Living Area } \\
\hline Urban & 92 & 21.65 & 333 & 78.35 & 425 & 40.55 \\
\hline Rural & 79 & 12.68 & 544 & 87.32 & 623 & 59.45 \\
\hline \multicolumn{7}{|l|}{ Living Region } \\
\hline Java & 101 & 20.12 & 401 & 79.88 & 502 & 47.90 \\
\hline Non-Java & 70 & 12.82 & 476 & 87.18 & 546 & 52.10 \\
\hline Total & 171 & 100.00 & 877 & 100.00 & 1,048 & 100.00 \\
\hline
\end{tabular}

Data Source: RAND (2015)

Table 2

Distribution of Immunization Status and Mother's Height Stunting and Non-Stunting Children in Indonesia

\begin{tabular}{|c|c|c|c|c|c|c|c|c|}
\hline \multirow{3}{*}{ Characteristic } & \multicolumn{4}{|c|}{ Incidence of Stunting } & \multirow{2}{*}{\multicolumn{2}{|c|}{ Total }} & \multirow{3}{*}{$p$} & \multirow{3}{*}{$\begin{array}{c}\text { OR } \\
(95 \% \mathrm{CI})\end{array}$} \\
\hline & \multicolumn{2}{|c|}{ Yes } & \multicolumn{2}{|c|}{ No } & & & & \\
\hline & $\mathrm{n}$ & $\%$ & $\mathrm{n}$ & $\%$ & $\mathrm{n}$ & $\%$ & & \\
\hline \multicolumn{9}{|l|}{ Immunization Status } \\
\hline Completed & 107 & 13.82 & 667 & 86.18 & 774 & 73.85 & \multirow[t]{2}{*}{$0.01 *$} & 1.78 \\
\hline Uncompleted & 64 & 22.54 & 220 & 77.46 & 284 & 27.10 & & $(1.26<\mathrm{OR}<2.52)$ \\
\hline \multicolumn{9}{|l|}{ Mother's Height } \\
\hline$<150 \mathrm{~cm}$ & 110 & 18.27 & 492 & 81.73 & 602 & 57.44 & \multirow[t]{2}{*}{$0.04 *$} & 1.41 \\
\hline$>150 \mathrm{~cm}$ & 61 & 13.68 & 385 & 86.32 & 446 & 42.56 & & $(1.004<\mathrm{OR}<1.98)$ \\
\hline Total & 171 & & 877 & & 1,048 & 100.00 & & \\
\hline
\end{tabular}

*significant if $\mathrm{p}<0.05(\alpha=0.05)$

Data Source: RAND (2015) 


\section{Child Age}

Stunting is a condition of growth retardation that happens in the first 1,000 day of life. The early life of children is a critical condition for growth and development (de Onis \& Branca, 2016). According to a study from Rachmi et al (2016) children have a higher risk in young age (22.9 years) to be stunted. The research that conduct by Hafid \& Nasrul (2017) showed that child aged 12-23 months have a higher risk to be stunted than a child aged 6-11 months. The number of older or younger children who stunted is lower than child aged three and four-year-old, according to the analysis. The number of stunted children decreased along with the older age (Altare, Delbiso, Mutwiri, Kopplow, \& Guha-Sapir, 2016). Children aged under three years is higher than children aged more than three years old. Prevention and early intervention are needed to ensure that mother's received adequate energy intake during pregnancy, children's adequate intake from breastfeed in the first six months of life and complementary feeding in the aged 7-23 month (de Onis \& Branca, 2016). According to Mazengia \& Biks (2018) study in Ethiopia showed that illiterate mother is a risk factor for stunting,.

\section{Child Sex}

Stunting can happen to both female and male children, but male children are at higher risk (Altare, Delbiso, Mutwiri, Kopplow, \& GuhaSapir, 2016). Table 2 shows that $47.20 \%$ of male children and $52.80 \%$ of female children are stunted. This result was different from Vonaesch et al (2017) study, which showed male children were 1.70 times at higher risk. The difference of anthropometry standard in height per age between a male and female child is one of the reasons for the difference in nutrition measurements in children (Permatasari \& Sumarmi, 2018). Male children are more active than female children, and this can cause stunting if the nutrition intake is inadequate (Widyaningsih, Kusnandar, \& Anantanyu, 2018).

\section{History of Infection}

Stunting occurs during the 1,000 days of life, and it is affected by chronic malnutrition and recurrent infection. Infection in children can reduce nutrition intake. Nutritional intake reduction in children due to disease will affect children's nutritional status. This study showed the number of stunted children who have a history of infection is higher than children who do not have a history of infection. Children who have a history of infectious disease are 0.13 more likely to be stunted (Permatasari \& Sumarmi, 2018). Infections can interfere with the absorption of children's nutrients, and children can be malnourished. If this continuously occurs, children will be at higher risk (Aridiyah, Rohmawati, \& Ririanty, 2015). Stunting is also affected by the infection of a communicable disease, but stunting children are also more at risk of experiencing recurrent infections (Oot, Sethuraman, Ross, \& Sommerfelt, 2016).

\section{Mother's Age During Pregnancy}

The WHO conceptual framework on childhood stunting indicates that pregnancy at a young age is related to stunting and noted it as a risk factor (WHO, 2014). Maternal age had a strong relationship with stunting in children (Victora et al., 2015). A mother who gave birth at a young age $(<20$ years old $)$ had a higher chance of having stunted children compared to a mother who gave birth at an older age (more than 20 years old). A study by Rahman, Napirah, Nadila, \& Bohari (2017) in Palu found that maternal age has a significant effect on stunting in children. The number of mothers in the high-risk period $(<20$ or $>35$ years old) was lower than the number of mothers at the ideal age; and surprisingly the chances of stunted children with a mother in the high-risk age is lower (14\% and 15\%) than with a mother at an ideal height (71\%). Younger and older maternal age increased the risk of under nutrition and foetal growth restriction, which can lead to low nutritional status. Chronic undernutrition status during an early age in children can lead to stunting. Young pregnancy indicates a young marriage and young mothers have a high risk of giving birth to low-birth-weight children, which can lead to stunting (Torlesse, Cronin, Sebayang, \& Nandy, 2016).

\section{Living Area}

Internal factors are not the only factors that influence stunting in children. External factors, such as household environment, also influences stunting (Aryastami \& Tarigan, 2017). Living in a rural area increases the risk of malnutrition, and the number of stunted children, compared to living in metropolitan areas (Schröders, Wall, Kusnanto, \& $\mathrm{Ng}, 2015$ ). Children who live in metropolitan areas are less at risk than children who live in rural areas. Living in a rural area means a child has less access to food, public health services, and sanitation (WHO, 2014). A study in Palu by Rahman, Napirah, Nadila, \& Bohari (2017) found 
that stunting is not only a problem in rural areas, but also in urban areas in Sulawesi. A study from Hall et al (2018) implied that mothers who live in a rural area lack knowledge about stunting. A study in Bangladesh showed that children in urban slum areas are at higher risk (Islam et al., 2018).

\section{Living Region}

Java island is the most populated island in Indonesia, and most stunted children live in Java $(56.70 \%)$. Other than that, economic growth in Java is higher than other regions and creates economic disparities. Java is the centre of finance, education, and health in Indonesia. The gaps between Java and non-Java area are not only in the economic sector, but also in the health and nutrition sectors. Central Nusa Tenggara, South Kalimantan, and South Sumatra island are the most vulnerable regions that face under-nutrition (Hanandita \& Tampubolon, 2015). According to the Riskesdas 2013, the province with the highest number of stunted children in Indonesia was East Nusa Tenggara, whose regional prevalence is higher than the national prevalence. Living in a non-Java area can increase the risk for children to be stunted compared to a child who lives in the Java region. The disparity in the Java area is affected by geographical differences in each region, income, and education (Ministry of Health RI, 2013).

\section{Immunisation Status}

During the 1,000 first days of life, children are put at significant risk if their nutritional intake is inadequate and they face recurrent infection. Recurrent infection in children can affect their growth and development, which can lead to stunting. Disease gives negative feedback to the nutritional status and if it happens over a long time it can increase the risk of stunting (Permatasari \& Sumarmi, 2018). The analysis statistics show that immunisation status is related to stunting. This result is in line with previous research. Children with uncompleted immunisation status are 1.78 more times at risk of stunting than children with completed immunisation status. Vaccinations have a role in reducing child mortality and children who receive vaccination have a lower risk. Early vaccination can reduce the odds of stunting in children, while delayed vaccination can increase the odds of stunting(Berendsen, Smits, Netea, \& van der Ven, 2016).

\section{Mother's Height}

Mother's height is a genetic condition that can be inherited by the child and determine their height in the future. Short mothers are likely to have short children. This study showed that a mother's height is related to stunting in children. Children with a mother whose height is less than $150 \mathrm{~cm}$ are 1.41 times more at risk than children with taller mothers. The result of this study is similar to Sinha et al (2018) research, which showed mothers with height $\leq 150 \mathrm{~cm}$ had a greater chance of having stunted children compared to children whose mothers were $>150 \mathrm{~cm}$ tall. Mothers with heights of $>150$ are less likely to have stunted children and are related to reduced stunting in children (Beal et al., 2018). Children who have a mother with height $<145 \mathrm{~cm}$ are more likely to be stunted than children with a taller mother (Phyo, Keiwkarnka, \& Mongkolchati, 2014).

\section{Research Limitation}

The primary limitation in this study is that the information was based on self-reports, and there was a possibility that the information was underor over-reported, except for the anthropometric measurements of the respondents that were measured by the surveyor.

\section{CONCLUSION}

This study concludes that stunting mostly occurs in children under 3 years of age, male children, and children who have a history of infection. Children born from a mother in the risk age $(<20$ or $>35)$ is more likely to be stunted. Children who live in the rural areas and non-Java areas have a greater possibility of being stunted than children who live in urban areas and Java. Immunisation status and maternal height are strongly related to stunting in children aged 2 to 5 years. Children with uncompleted immunization status were 1.78 times more likely to be stunted, and children with mother's height less than $150 \mathrm{~cm}$ were 1.41 times more at risk. Suggestions for future study include using a larger sample, more variables, and a different study design to enlarge the field.

Finally, as prevention and intervention are crucial for eradicating stunting, the government should take proper action to increase the number of children with complete immunisation in order to reduce the number of stunted children. 


\section{CONFLICT OF INTEREST}

The authors declare that no conflict of interest in this study.

\section{ACKNOWLEDGMENT}

We would like to thank RAND Coorporation who provided Indonesian Family Life Survey-5 data that has been used for this research. We sincerely appreciate the participants, supervisors, and data collectors for their cooperation during the data collection.

\section{REFERENCES}

Altare, C., Delbiso, T. D., Mutwiri, G. M., Kopplow, R., \& Guha-Sapir, D. (2016). Factors associated with stunting among preschool children in Southern Highlands of Tanzania. Journal of Tropical Pediatrics, 62(5), 390-408. https://doi.org/10.1093/tropej/fmw024

Aridiyah, F. O., Rohmawati, N., \& Ririanty, M. (2015). Faktor-faktor yang mempengaruhi kejadian stunting pada anak balita di wilayah pedesaan dan perkotaan. E-Jurnal Pustaka Kesehatan, 3(1), 163-170.

Aryastami, N. K., \& Tarigan, I. (2017). Kajian kebijakan dan penanggulanagan masalah gizi stunting di Indonesia. Buletin Penelitian Kesehatan, 45(4), 233-240. https://doi.org/10.22435/bpk.v45i4.7465.233240

Beal, T., Tumilowicz, A., Sutrisna, A., Izwardy, D., \& Neufeld, L. M. (2018). A review of child stunting determinants in Indonesia. Maternal and Child Nutrition, 14(4), 1-10. https://doi.org/10.1111/mcn.12617

Berendsen, M. L. T., Smits, J., Netea, M. G., \& van der Ven, A. (2016). Non-specific effects of vaccines and stunting: timing may be essential. EBioMedicine, 8, 341-348. https://doi.org/10.1016/j.ebiom.2016.05.010

de Onis, M., \& Branca, F. (2016). Childhood stunting: a global perspective. Maternal and Child Nutrition, 12(1), 12-26. https://doi.org/10.1111/mcn.12231

Dewana, Z., Fikadu, T., Facha, W., \& Mekonnen, N. (2017). Prevalence and predictors of stunting among children of age between 24 to 59 months in Butajira Town and surrounding district, Gurage Zone, Southern Ethiopia. Health Science Journal, 11(4), 1-6. https://doi.org/10.21767/1791-809X.1000518
Hafid, F., \& Nasrul. (2017). Faktor risiko stunting pada anak usia 6-23 bulan di Kabupaten Jeneponto. Indonesian Journal of Human Nutrition, 3(1), 42-53. https://doi.org/10.21776/ub.ijhn.2016.003.su plemen.5

Hall, C., Bennett, C., Crookston, B., Dearden, K., Hasan, M., Linehan, M., ... West, J. (2018). Maternal knowledge of stunting in Rural Indonesia. International Journal of Child Health and Nutrition, 7(4), 139-145. https://doi.org/10.6000/19294247.2018.07.04.2

Hanandita, W., \& Tampubolon, G. (2015). The double burden of malnutrition in Indonesia: social determinants and geographical variations. SSM - Population Health, 1, 1625. https://doi.org/10.1016/j.ssmph.2015.10.002

Islam, M. M., Sanin, K. I., Mahfuz, M., Ahmed, A. M. S., Mondal, D., Haque, R., \& Ahmed, T. (2018). Risk factors of stunting among children living in an urban slum of Bangladesh: findings of a prospective cohort study. BMC Public Health, 18(1), 1-13. https://doi.org/10.1186/s12889-018-5101-x

Leroy, J. L., \& Frongillo, E. A. (2019). Perspective: what does stunting really mean? a critical review of the evidence. Advances in Nutrition, 10(2), 196-204. https://doi.org/10.1093/advances/nmy101

Mazengia, A. L., \& Biks, G. A. (2018). Predictors of stunting among school-age children in Northwestern Ethiopia. Journal of Nutrition and Metabolism, 1-7. https://doi.org/10.1155/2018/7521751

Ministry of Health RI. (2013). Indonesia basic health research (Riskesdas) 2013. Ministry of Health RI. Jakarta.

Ministry of Health RI. (2018). Nutrition status monitoring handbook 2017. Jakarta: Ministry of Health RI.

Oot, L., Sethuraman, K., Ross, J., \& Sommerfelt, A. E. (2016). The effect of chronic malnutrition (stunting) on learning ability, a measure of human capital: a model in profiles for country-level advocacy. FANTA: Food and Nutrition Technical Assistance III Project, 16(2), 1-8.

Permatasari, D. F., \& Sumarmi, S. (2018). Differences of born body length, history of infectious diseases, and development between stunting and non stunting toddlers. Jurnal Berkala Epidemiologi, 6(2), 182-191. https://doi.org/10.20473/jbe.v6i22018.182- 
191

Phyo, S. W., Keiwkarnka, B., \& Mongkolchati, A. (2014). Factors related to stunting status of the children aged uncer two years in Magway Township, Myanmar. Journal of Public Health and Development, 12(3), 3-15.

Rachmi, C. N., Agho, K. E., Li, M., \& Baur, L. A. (2016). Stunting, underweight and overweight in children aged 2.0-4.9 years in Indonesia: Prevalence trends and associated risk factors. PLoS ONE, 11(5), 1-17. https://doi.org/10.1371/journal.pone.0154756

Rahman, N., Napirah, M. R., Nadila, D., \& Bohari. (2017). Determinants of stunting among children in urban families in Palu, Indonesia. Pakistan Journal of Nutrition, 16(10), 750756. https://doi.org/10.3923/pjn.2017.750.756

RAND. (2015). IFLS data and documentation. Retrieved July, 23, 2019, from https://www.rand.org/labor/FLS/IFLS.html

Schröders, J., Wall, S., Kusnanto, H., \& Ng, N. (2015). Millennium development goal four and child health inequities in Indonesia:a systematic review of the literature. PLoS ONE, 10(5), 1-28. https://doi.org/10.1371/journal.pone.0123629

Sinha, B., Taneja, S., Chowdhury, R., Mazumder, S., Rongsen-Chandola, T., Upadhyay, R. P., ... Bhan, M. K. (2018). Low-birthweight infants born to short-stature mothers are at additional risk of stunting and poor growth velocity: evidence from secondary data analyses. Maternal and Child Nutrition, 14(1), 1-9. https://doi.org/10.1111/mcn.12504

TNPK. (2017). 100 kabupaten/kota prioritas untuk penanganan anak kerdil (stunting) (1st ed.). Jakarta: Tim Nasional Percepatan Penanggulangan Kemiskinan.

Torlesse, H., Cronin, A. A., Sebayang, S. K., \& Nandy, R. (2016). Determinants of stunting in Indonesian children: evidence from a cross-sectional survey indicate a prominent role for the water, sanitation and hygiene sector in stunting reduction. BMC Public Health, 16(1), 1-11. https://doi.org/10.1186/s12889-016-3339-8

Victora, C. G., Villar, J., Barros, F. C., Ismail, L. C., Cameron, C., Papageorghiou, A. T., ... Kennedy, S. H. (2015). Anthropometric characterization of impaired fetal growth risk factors for and prognosis of newborns with stunting or wasting. JAMA Pediatrics, 169(7), 1-10. https://doi.org/10.1001/jamapediatrics.2015.1 431

Vonaesch, P., Tondeur, L., Breurec, S., Bata, P., Nguyen, L. B. L., Frank, T., ... Vray, M. (2017). Factors associated with stunting in healthy children aged 5 years and less living in Bangui (RCA). PLoS ONE, 12(8), 1-17. https://doi.org/10.1371/journal.pone.0182363

WHO. (2014). Childhood stunting: challenges and opportunities. Retrieved July, 23, 2019, from

https://apps.who.int/iris/bitstream/handle/106 65/107026/WHO_NMH_NHD_GRS_14.1_e ng.pdf;jsessionid $=3 \mathrm{D} 242 \mathrm{~A} 4822 \mathrm{FC} 18 \mathrm{~F} 029 \mathrm{~A} 3$ 9D1620E421FE? sequence $=1$

Widyaningsih, N. N., Kusnandar, \& Anantanyu, S. (2018). Keragaman pangan, pola asuh makan dan kejadian stunting pada balita usia 24-59 bulan. Jurnal Gizi Indonesia, 7(1), 22-29. https://doi.org/10.14710/jgi.7.1.22-29 